\title{
Powering Options of the Un-electrified Sub-villages around Bali through Adoption of Renewable Generation Scheme
}

\author{
Nyoman S Kumara, WG Ariastina, W Sukerayasa, IAD Giriantari \\ Department of Electrical Engineering, Faculty of Engineering Udayana University, Bali
}

\begin{abstract}
Bali has seen relatively rapid infrastructure development to support its status as the main tourist destination in Indonesia. This has transformed the island into a province that enjoys good economy thus achieves relatively good living standard for most of its population. However, some villages in Bali are still without access to electricity due to reasons associated with topography of the villages in which they are mostly located in high mountainous area or deep in the valleys. Such topographical characteristic has hindered the expansion of utility's grid due to high initial cost and less attractive energy sales in the village. Meanwhile, world has recognized that electricity is a necessary support for achieving many of the millennium development goals that set to improve the quality of human life. Moreover, our constitutional mandates stipulate that earth, water and any resources thereof should be utilized to benefit our citizen irrespective of geographical and topographical condition of their location.
\end{abstract}

The research reported here is the result of investigation on the current status of un-electrified sub-villages around Bali. Based on our research, the amount of power required to electrify those areas is less than two megawatt. Solutions to provide electricity to the affected area are discussed. Discussion includes the availability of local resources such as natural, social and human resources available in those areas in view of developing locally managed energy plants. Renewable generation technology such as solar photovoltaic, microhydro and wind turbine is discussed in order to provide a green and sustainable electrical energy supply for basic use in the affected area around Bali.

Keywords: Bali electricity system, Bali rural electrification, un-electrified sub-villages, renewable electricity generation, solar photovoltaic, microhydro

\section{INTRODUCTION}

Bali is well known for international tourist destination and has become one of the best places in Asia for holidays which now also include venue for business meeting and conference. It is this trend that has given Bali many advantages in term of infrastructure development compared to other places in Indonesia. The government both central and local are keen to develop infrastructure around the island to ensure safety and comfort of the holiday makers or visitors when they stay and travel on the island. Moreover, industry and business have been investing heavily on the development of tourism related facilities such as hotel, villas, restaurants, shopping malls, leisure parks, etc. To a great extend, this development has been seen as the major sector that drives the economy of the island and turning Bali into one of the best place to attract domestic and international investments. As a result, most of the population has enjoyed better life and good standard of living. For example, good road access is virtually everywhere on the island. Schools, local health clinics, basic needs supplies, telecommunication networks and its coverage, etc are relatively well distributed around the island.

However, In contrast with its rapid development it appears some areas in Bali are still without access to electricity, a basic need in today's modern life. A village household without electricity can still do its normal life but limited to the basic function and with low or no opportunity to open up ways for improving their quality of life. The lack of electricity has hampered their access to information which in today's information based society becomes a necessity. 
PT PLN is state electricity enterprise that has been given the sole responsibility to manage the national electricity sector. Its role is, together with private sectors to generate, and currently transmit, distribute, and sell the electricity to people and industry throughout the country. In Bali, the electricity system is managed by PLN Distribusi Bali. While it follows business principles PLN also has to observe its public service obligation by providing energy access to economically less viable areas. Since 1995, PLN Bali has connected all of the villages around Bali to its distribution networks, hence achieved $100 \%$ electrification ratio. However, many of sub-villages are not yet covered. A subvillage is the smallest administration unit in the village's administration. A village usually comprises of one or more sub-villages. These sub-villages are scattered all around Bali and normally located far from the center of the village and mostly in the remote areas such as high in the mountain or on the deep of the valleys hence access to this area is very difficult.

This paper presents findings on the current status of un-electrified villages in Bali. The research involves assessment on local natural resources available in the community including human and social resources to support locally managed small scale electricity generation plants. Options will be reviewed to include extending existing utility's grid to reach for this area. Renewable technology generation will be an important consideration in reviewing solutions taking into account geographic characteristics of the villages. The authors acknowledge the financial support given by Lemlit UNUD for this research as part of the national strategic research program.

\subsection{PLN Bali and Lack of Power Capacity}

Peak load of Bali's electricity has reached around 493 MW while its maximum capacity is around 580 MW. From an ideal power system operation point of view such condition can indicate a critical system. A normal operating condition for power system is to have reserved capacity known as spinning reserved which equals to one of the largest generating unit within the system. With this condition met, high reliability and continuity of power supply can be maintained. In contrast, lack of sufficient spinning capacity can lead to less reliable power supply as customers may experience power cuts both due to scheduled maintenance or systems disturbance.

The growth of power demand in Bali has been high due to rapid development of tourism industry and its associated industries. Currently, the utility is lagging behind the demand hence customers are queuing to get their home and business connected. PLN Bali stated that currently around 50.000 customers are waiting for power connection. Lack of power capacity is the single major reason for this problem. A number of power plants has been proposed and even has started their initial construction stage but so far none of the proposed plan is actually progressing to the extend where power can be produced. The proposed power plants are coal-fired plant in Celukan Bawang, in Sukadana Karangasem, coalfired power plant in Nusa Penida, geothermal plant in Bedugul, and the construction of extra high voltage transmission cable suspended above Bali straight capable of delivering in excess of $1000 \mathrm{MW}$ from Jawa's power system. Until any of the proposed plant actually produces its power, the customer in Bali is likely to experience wide ranging of problems starting with less reliable supply up to no power at all and waiting for their premises to be connected to utility's network.

\subsection{Renewable Generation Technology for Rural Area}

Currently, all of the electric power in Bali is generated from fossil fuel based technology such as diesel plants and oil-fired plants in Pesanggaran (120 MW), Gilimanuk (130 MW), and Pemaron (80 MW), and from Jawa submarine transmission cable ( 2 x $110 \mathrm{MW}$ ) which are also generated from coalfired plants. Although Indonesia has lots of fossil based resources such as oil, gas, and coal but based these natural resources are non-renewable and their reserves are diminishing due to high demand. Once, Indonesia was member of OPEC, organization of countries that export oil around the world, but because the increasing domestic consumption had exceeded our oil production, it has turned Indoneisa to become net importer country. With respect to gas resources, while today Indonesia still plays 
important role in the world gas supply, it is predicted that approaching 2020 gas import may be started to meet domestic demand. Similar story applies to our coal resource although the national reserve is estimated will be sufficient for the next 70 to 100 years. Today, the impact of the application of fossilbased technology to the environment is clear and world has started to take measures to reduce its uses and mitigate its impacts.

Renewable generation technology is a solution that many predict will help human being to carry on moving forward when all world fossil-based fuel has been fully depleted. Some of the technologies have achieved stage where society can already benefit from by using systems such as solar photovoltaic, hydropower, and wind turbine. The mass application of renewable technology is currently hindered by constraints associated with low price of fossil based energy and the high initial investment cost for renewable technology. But driven by limited nature of the conventional reserves, advancement of technology, better understanding of environmental impacts hence commitment for cleaner and sustainable nature of renewable energy are the motive for the penetration of this technology in our society.

Indonesia is one of the first countries that benefit from photovoltaic systems. Our geographical location lends itself a promising potential as source of renewable energy as the sun shine nearly all year round. So far, photovoltaic system is mainly used for electrification in rural areas started back to the 1980s where the first solar home system (SHS) was installed in the village of Sukatani in West Java. Since then, various projects have been implemented around Indonesia but mainly for remote areas in which the systems are used for water pumping, lighting, telecommunication, and medical storage. As of today, photovoltaic systems or widely known as Pembangkit Listrik Tenaga Surya (PLTS) has achieved stage where the system and its components are widely available in Indonesia. The author has published work related to the availability of photovoltaic system and its components in Indonesian market, (Kumara et all, 2010). And today, the total installed capacity of solar power in Indonesia is around $80 \mathrm{MW}$.
Microhydro is small scale application of hydropower, the earliest natural force that is utilized to produce electricity. A microhydro system does not require massive investment, land, nor water resource as is in the development of dam-type hydropower plant. This makes microhydro is suitable for areas with relatively small water or river. Microhydro technology development has enabled production of electricity in the range of $500 \mathrm{~W}$ up to tens of kilowatt depending on the water potential. The application of microhydro in Bali peaked around the 1980s in which over 500 microhydro units was installed. However, during this time PLN expanded their grid down to rural area and led to the disappearance of this type of community based generation plant. As of today, the only microhydro site that is fully running is the PLTMH Karangasem with capacity of $25 \mathrm{~kW}$. The system was built by ministry of energy and mineral resources and handed to the local cooperative as a demonstration project. The power is sold PLN which is connected to medium voltage distribution network. Currently, total national microhydro installation is estimated at around $80 \mathrm{MW}$.

Wind energy is also one of the first natural energy converted into a more useful form of energy. Today, wind energy, in some part of the world, can play great role in providing electricity. The technology has advanced and currently made available small scale wind turbine of less than a kilowatt up to tens of megawatt tower depending on the site or wind potential. Indonesia as an archipelago country with massive coastal area holds high potential for wind electricity. So far, national progress on this technology has been somewhat slow due to lack of national wind resource assessment map. However, assessment in various places around the country is progressing followed by construction of small scale wind turbine.

\section{RESULTS AND DISCUSSION}

The current status of the un-electrified sub-villages around Bali has been published by the authors but for quick reference the modified table is presented again on Table 1, (Kumara et all, 2009) 
Table 1: Un-electrified sub-villages around Bali.

\begin{tabular}{|c|l|c|}
\hline No. & \multicolumn{1}{|c|}{ Sub-villages } & $\begin{array}{c}\text { District/(Sub- } \\
\text { district) }\end{array}$ \\
\hline 1 & $\begin{array}{l}\text { Tandang Buana Sari, } \\
\text { Gunung Kunyit, Saap, } \\
\text { Tanah Gambir, Giringan, } \\
\text { Kubusalya, Kuum, Kayu } \\
\text { Selem, Peradi, Kendal, } \\
\text { Kayu Padi, Masahan, } \\
\text { Tiangan }\end{array}$ & $\begin{array}{c}\text { Bangli/ } \\
\text { (Kintamani) }\end{array}$ \\
\hline 2 & $\begin{array}{l}\text { Mengandang, Kelandis, } \\
\text { Rendetin, Punggang }\end{array}$ & $\begin{array}{c}\text { Buleleng/ } \\
\text { (Kubutambahan, } \\
\text { Banjar) }\end{array}$ \\
\hline 3 & $\begin{array}{l}\text { Temukus, Kesimpar, } \\
\text { Cegi, Balong, Manik Aji, } \\
\text { Daya, Pengalusan, } \\
\text { Darmaji, Pucang, Bunga, } \\
\text { Pedahan Kaja, Kacang } \\
\text { Balung, Belubuh }\end{array}$ & $\begin{array}{c}\text { Karangasem/ } \\
\text { (Rendang, } \\
\text { Kubu) }\end{array}$ \\
\hline
\end{tabular}

As of today, the sub-villages listed on Table 1 are still not connected to the PLN's house connection or Sambungan Rumah (SR). This connection is normally done by PLN that connect customer incoming terminal and the low voltage distribution network.

The following subsection discusses various options for powering these sub-villages. An option to connect them to the utility's network is discussed taking into account Bali's electricity capacity, reliability, power losses, and distribution network. Option on powering the affected area with local renewable resources is also discussed.

\subsection{Expansion of PLN's Grid to Reach Remote Sub- villages}

One immediate solution for powering the subvillages is through the expansion of PLN's distribution network and connects these houses to the grid. In order to do that, power capacity requirement for each of the sub-villages must be determined. Table 2 shows total power required for each of the sub-villages.
Table 2: Power requirement of un-electrified sub-villages in Bali.

\begin{tabular}{|c|c|c|}
\hline No. & Sub-villages & Power $(\mathbf{k W})$ \\
\hline 1 & Cegi & 26.80 \\
\hline 2 & Balong & 93.60 \\
\hline 3 & Manik Aji & 105.30 \\
\hline 4 & Daya & 51.30 \\
\hline 5 & Pengalusan & 29.25 \\
\hline 6 & Darmaji & 43.65 \\
\hline 7 & Pucang Bunga & 55.60 \\
\hline 8 & Pedahan Kaja & 45.00 \\
\hline 9 & Kacang Balung & 81.45 \\
\hline 10 & Temukus & 81.45 \\
\hline 11 & Tandang Buana Sari & 32.40 \\
\hline 12 & Gunung Kunyit & 8.55 \\
\hline 13 & Saap & 41.85 \\
\hline 14 & Tanah Gambir & 50.40 \\
\hline 15 & Giringan & 39.15 \\
\hline 16 & Kubusalya & 28.35 \\
\hline 17 & Kuum & 32.40 \\
\hline 18 & Kayu Selem & 54.00 \\
\hline 19 & Peradi & 44.10 \\
\hline 20 & Kendal & 19.35 \\
\hline 21 & Kayu Padi & 26.10 \\
\hline 22 & Masahan & 22.05 \\
\hline 23 & Tiangan & 5.40 \\
\hline 24 & Madia & 70.20 \\
\hline 25 & Bunut & 42.75 \\
\hline 26 & Mengandang & 90.00 \\
\hline \multirow[t]{2}{*}{27} & Kelandis & 135.00 \\
\hline & Total & $1,345.5$ \\
\hline
\end{tabular}

Data on this table is taken from publication by the utility, local government and from our surveys in the affected sub-villages.

It is clear from the Table 2 that the additional power required to electrify the sub-villages around Bali is relatively small which equal to amount of less than two megawatts. However, a closer look into Bali's electricity systems clearly shows that this additional amount will certainly add pressure to the system that is already in critical condition. As part of the research, the authors have also published work related to Bali's energy balance and is presented below for quick reference (Ariastina et all, 2009). 
Table 3: Predicted power balance of Bali electricity system

\begin{tabular}{|c|c|c|c|c|c|c|c|c|c|}
\hline Year & $\begin{array}{c}\text { Energy } \\
\text { demand }\end{array}$ & Losses & $\begin{array}{c}\text { Net } \\
\text { energy } \\
\text { demand }\end{array}$ & $\begin{array}{c}\text { Load } \\
\text { factor }\end{array}$ & $\begin{array}{c}\text { Peak } \\
\text { demand }\end{array}$ & Generating & (N-1) & $\begin{array}{c}\text { Normal } \\
\text { capacity } \\
\text { condition }\end{array}$ & $\begin{array}{c}\text { Reserve } \\
\text { reserve }\end{array}$ \\
\hline & GWh & $\%$ & GWh & $\%$ & MW & MW & MW & MW & MW \\
\hline 2009 & 2,724 & 6.27 & 2,895 & 63 & 522.01 & 586.90 & 456.90 & 64.89 & -65.11 \\
\hline 2010 & 2,960 & 6.25 & 3,145 & 64 & 562.64 & 586.90 & 456.90 & 24.26 & -105.74 \\
\hline 2011 & 3,217 & 6.22 & 3,417 & 65 & 599.12 & 586.90 & 456.90 & -12.22 & -142.22 \\
\hline 2012 & 3,497 & 6.19 & 3,714 & 66 & 638.43 & 586.90 & 456.90 & -51.53 & -181.53 \\
\hline 2013 & 3,803 & 6.16 & 4,038 & 68 & 680.85 & 586.90 & 456.90 & -93.95 & -223.95 \\
\hline 2014 & 4,139 & 6.13 & 4,392 & 69 & 726.69 & 586.90 & 456.90 & -139.79 & -269.79 \\
\hline 2015 & 4,506 & 6.10 & 4,781 & 70 & 776.32 & 586.90 & 456.90 & -189.42 & -319.42 \\
\hline 2016 & 4,909 & 6.07 & 5,207 & 72 & 830.13 & 586.90 & 456.90 & -243.23 & -373.23 \\
\hline 2017 & 5,351 & 6.04 & 5,675 & 73 & 888.59 & 586.90 & 456.90 & -301.69 & -431.69 \\
\hline 2018 & 5,838 & 6.01 & 6,189 & 74 & 952.21 & 586.90 & 456.90 & -365.31 & -495.31 \\
\hline
\end{tabular}

The last column of Table 3 shows that since 2009 Bali has started to experience power deficit and this will continue into the future unless new power plants or addition of power capacity is in place. Considering this condition, it is difficult to see that provision of power for the un-electrified areas of Bali can be taken from expanding PLN's grid.

From investment point of view, to build medium voltage distribution network to cover houses scattered over wide and difficult topography and setting up house or residential connection will require massive investment. This will add problem to the utility which now is in under capacity condition. The PLN clearly states that they do not have enough financial capacity to support their development. Meanwhile, the role of the independent power producers (IPPs) is still not optimum. Therefore, solution of providing power for these remote villages should then be looked elsewhere or using measures by combining different approaches.

\subsection{Renewable Energy for Remote Sub-villages}

Bali is rich with sun light hence has high potential for solar photovoltaic application. Our surveys found that all of these sub-villages receive a fair amount of sun light almost all year round. The sun can be seen from morning until late afternoon particularly in the Kintamani and Kubu area. In one of the sub-villages in Kintamani, sub-village Gunung Kunyit, already they have solar home system installed on their roof top, thanks to the program developed by the ministry of mineral and mine resources. A picture showing landscape and roof top solar home system is shown in Figure 1. The solar home system is mainly used for lighting and can be used to power radio or small television which is a typical use of electricity in the village.

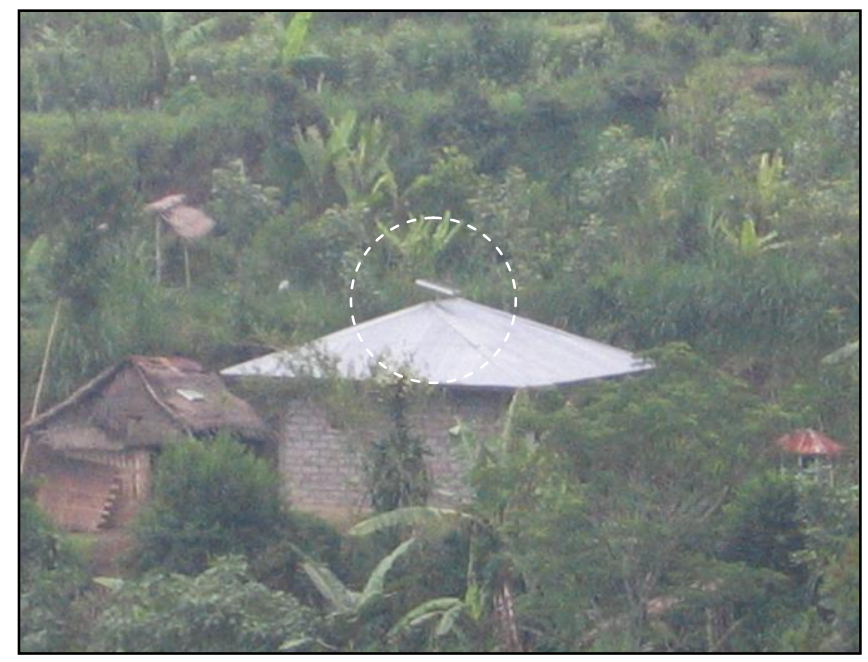

Figure 1: Roof top solar home system in Gunung Kunyit

A lot more of these sub-villages can benefit from the use of solar photovoltaic due to the fact their topographical characteristics is somewhat difficult to be served by PLN. The house is normally scattered over wide and contoured area climbing as high as 2000 meter above sea level and then down along hills. Road access to some of the villages is literally non existent except through very steep footpaths ascending on the hills side.

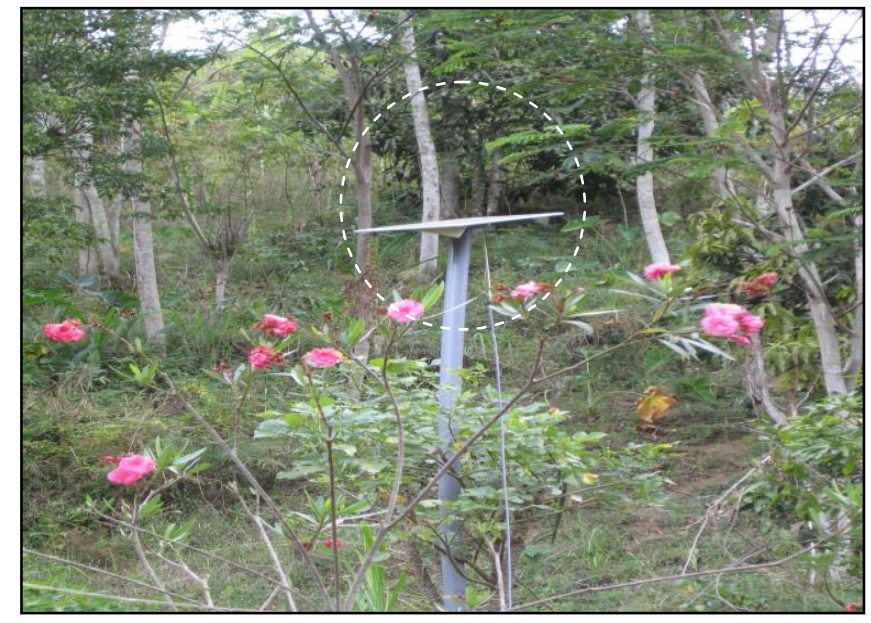

Figure 2: PV panel in Daya sub-village Kubu 
Some part of the sub-villages in Kubutambahan and Bontihing are scattered within densely green forest area. This makes solar application in these areas might not be the best approach due to high trees or plantation that surrounds villagers' houses. Fortunately, the sub-villages in this area have other natural resources to be explored. The area has good potential of tapping water resources that is available in the form of stream and waterfall. These can be harnessed to produce electricity using microhydro technology. In fact, according to villagers that in the past they had seen such system installed along the Daya river but since the village electrification program of the PLN somehow reached part of the villages, the plant was abandoned. Similar story was told regarding microhydro around Bali.

Wind turbine is relatively new technology that enters Indonesia. There is little information available to see if historically we have used wind power for useful works except for the fisherman who used it to power their ships. Nevertheless, geographical location of Indonesia poses wind potential. Wind map of Indonesia produced by LAPAN indicates that our wind power varies from place to place but generally it has speed range of 3 to $12 \mathrm{~m} / \mathrm{s}$. Survey on the literature suggest that wind in Indonesia seems to be toward the lower end of the spectrum. In order to fully understand the potential of wind energy in Indonesia particularly in Bali, a more comprehensive wind map for each of part of Bali should be established followed by assessment of wind in the higher altitude prior to any project implementation.

Local organization is any forms of organization that exists in the village community which can be used to support any rural development program. One advantage of having local organization is that sustainability of the program can be maintained. In the case of renewable power plant, the village social organizations will simplify the commissioning of the system as well as the regular maintenance once the plant is handed over to the community. The organization will ensure that the facilities will be continuously maintained and safeguarded by local residents. From our surveys at these villages, we found that almost all villages have local organization such us subak which is a traditional farming organization, traditional village administration or banjar organization, as well as youth organization or
Sekeha Teruna Teruni (STT). The youth organization is particularly important as they are young and have great interest to new technology.

Financing is still the biggest challenge for the rural community as well as communities in general in acquiring the renewable generation technology. So far, most if not all the installed photovoltaic system and microhydro plants in Bali are built and financed by either the government or other organization. However, as we found that one family in Kubu had bought small solar home system and installed in their home without any external assistance. While this is unlikely to indicate the majority of household in the village but this suggests that some of them already seen the benefit of having photovoltaic system in their home. A lot of works and program therefore need to be done to persuade wider participation by our society. Supply and construction of renewable system supported with financial incentive, subsidies, or even donation are all options that can be exploited for financing rural electricity program. Equally important is the availability of local show case projects which are integrated with training and support to ensure sustainability of the system and its benefit to the community.

\section{CONCLUSION}

This paper has presented the current status of unelectrified sub-villages in Bali. A number of reasons have been identified as to why these sub-villages have not been connected to the PLN's low voltage residential connection networks. Firstly, location of these sub-villages is very remote as they are high in the mountainous area or deep in the valleys. This consequently will demand huge initial investment for extending the existing power distribution network. Secondly, Bali electricity system is now experiencing critical condition due to lack power capacity. There has been little addition of power to the system for the last ten to fifteen years but demand from the more prospective customers, i.e. customers from within the central of Bali's economy, is rapidly increasing. The combination of these factors has played significantly in hindering the utility company to reach these villages. 
Considering the characteristic of consumers in the sub-villages and taking into account the condition of electricity system therefore decentralised power system will be more suitable for powering these subvillages. In general, renewable generation technology should be given priority due to the fact that conventional based system will rely on outsourced fuels which is again difficult due to lack of access to these villages. In particular, solar photovoltaic system is potential to be used for subvillages in Kintamani and Kubu. For Kubutambahan and Bontihing areas, technology based on hydropower is promising due to the availability of rivers, streams, and waterfalls.

Consorted efforts consisting utility company, local and central government, industries and universities should be able to draw solution in providing electricity, one of the basic need, for the people who live in these villages.

\section{REFERENCES}

Ariastina, W.G., Setiawan, I N., Kumara, I N.S., Bali Electrical Energy Demands: Forecast and Supply Strategies, Prosiding Seminar Nasional XIV-FTI-ITS, Surabaya, 22 23 Juli 2009, ISBN: 9795450433.

Badan Perencanaan Pembangunan Daerah Pemerintah Provinsi Bali, "Rencana Umum Ketenagalistrikan Daerah (RUKD) Provinsi Bali Tahun 2004”, Denpasar, 2004.

Badan Pusat Statistik Provinsi Bali, "Bali Dalam Angka 2005", Denpasar, 2005.

Badan Pusat Statistik Provinsi Bali, "Bali Dalam Angka 2006", Denpasar, 2006.

Badan Pusat Statistik Provinsi Bali, "Bali Dalam Angka 2007”, Denpasar, 2007

Bappeda Bali, "Kebijakan dan Pengembangan Energi Listrik di Bali”, Badan Perencanaan Pembangunan Daerah (Bappeda) Propinsi Bali, 2006.

Departemen Energi dan Sumber Daya Mineral, "Blueprint Pengelolaan Energi Nasional 2005-2025”, Jakarta, 2005.

DESDM, "Kebijakan Pengembangan Energi Terbarukan Dan Konservasi Energi (Energi Hijau)", Departemen Energi Dan Sumber Daya Mineral, Jakarta, Desember 2003.
Elektro Unud - YLKI Bali, "Semiloka Potensi Krisis Listrik di Bali dan Alternatif Solusinya", Yayasan Lembaga Konsumen Indonesia (YLKI Bali), Teknik Elektro UNUD, dan Yayasan Kertaning Jagat Bali (KERJA Bali), Denpasar, 2005.

Kumara, N.S., Ariastina, W.G., Giriantari, I.A.D., Sukerayasa, W., Electricity Access for Remote Sub-villages Around Bali: Local Resources and Technology Assessments, Prosiding Seminar Nasional XIV-FTI-ITS, Surabaya, 22 23 Juli 2009, ISBN : 9795450433.

Kumara, N.S., Pembangkit Listrik Tenaga Surya (PLTS) Skala Rumah Tangga Urban Dan Ketersediaanya di Indonesia, Disampaikan untuk diterbitkan dalam Jurnal Teknologi Elektro, Juli 2010.

Ikegami, T., Assesment of global potential of solar and wind energy using GIS, the $13^{\text {th }}$ AIM International Workshop, Feb 18, 2008. 